\title{
(อ) OPEN ACCESS \\ Support from superiors reduces depression in Republic of Korea military officers
}

\author{
Seon Yeong Woo, ${ }^{1,2}$ H J Kim 주 ${ }^{2,3}$ B R Kim, ${ }^{2,3}$ H C Ahn, ${ }^{4}$ B N Jang, ${ }^{2,3}$ E-C Park ${ }^{5,6}$
}

'Department of Nursing Graduate School, Yonsei University, Seodaemun-gu, Seoul, Republic of Korea

${ }^{2}$ Army Cadet Military School, Training \& Doctrine Command, Republic of Korea Army, Goesan, Republic of Korea ${ }^{3}$ Department of Public Health, Graduate School, Yonsei University, Seodaemun-gu, Seoul, Republic of Korea ${ }^{4} 12$ Division, Repulic of Korea Amry, Hwacheon, Gangwon, Republic of Korea

Institute of Health Services Research, Yonsei University, Seodaemun-gu, Seoul, Republic of Korea

${ }^{6}$ Department of Preventive Medicine, Yonsei University College of Medicine,

Seodaemun-gu, Seoul, Republic of Korea

\section{Correspondence to}

Professor E-C Park, Institute of Health Services Research, Yonsei University, Seoul 03722 . Republic of Korea; ecpark@ yuhs.ac

Received 10 October 2019 Revised 3 December 2019 Accepted 10 December 2019

\section{Check for updates}

(c) Author(s) (or their employer(s)) 2020. Re-use permitted under CC BY-NC. No commercial re-use. See rights and permissions. Published by BMJ.

To cite: Woo SY, Kim HJ, Kim BR, et al. BMJ Mil Health Epub ahead of print: [please include Day Month Year]. doi:10.1136/

jramc-2019-001343

\begin{abstract}
Background The prevalence of depression is relatively high in the Korean military. Social support is a protective factor against depression and is classified into four categories: emotional support-having the sense of feeling loved; instrumental support-receiving material assistance; informational support—receiving advice; appraisal support-feeling valued and respected for one's abilities. Objective To investigate the effect of support from one's superior on depression among Republic of Korea (ROK) military officers.
\end{abstract}

Methods 2047 participants from the 2015 Military Health Survey were included in the study. The Korean version of the Beck Depression Inventory was used to measure depression, and a self-reported questionnaire was used to assess support from one's superior. A chisquared test and multiple logistic regression were used to analyse the data.

Results Of the 2047 participants, 177 (8.6\%) had depression. Military officers who did not receive support from their superior were more likely to have depression than than those who did receive support (OR=2.09, $95 \% \mathrm{Cl} 1.30$ to 3.36 ). Additionally, military personnel who did not receive emotional or appraisal support were more likely to have depression (emotional support: $\mathrm{OR}=2.37$, $95 \% \mathrm{Cl} 1.31$ to 4.29 ; appraisal support: $\mathrm{OR}=1.56,95 \% \mathrm{Cl}$ 1.48 to 2.75$)$.

Conclusions Our study found that depression in military officers was associated with lack of support from superiors. In particular, emotional support and appraisal support had a statistically significant effect. Therefore, we suggest that the ROK armed forces consider early intervention and management for high-risk groups. A social support programme and organisational atmosphere are also needed to improve supportive ability and skills of superiors.

\section{INTRODUCTION}

Depression is a common mental disorder worldwide. According to the World Health Organization's global health estimates (2017), 4.4\% of the world's population have depression. ${ }^{1}$ Depression will be the main leading cause of disease in humanity by $2030 .^{2}$ Recognising the worldwide increase in depression, the Republic of Korea (ROK) has been conducting a mental health survey since 2001. According to the 2016 Survey of Mental Disorders in the ROK, the prevalence of major depressive disorder was $5.0 \%$ (men: 3.0\%; women: 6.9\%), ${ }^{3}$ which is higher than the global prevalence of depression (4.4\%). Additionally, the suicide rate in the ROK ranks second among countries in the Organisation for Economic Co-operation and Development. ${ }^{4}$ Management of depression in Korean society is urgently needed because depression negatively affects the person and society. ${ }^{56}$

Risk factors for depression include genetic and sociodemographic factors. The military environment could be a risk factor for depression. In a closed and poor military environment, ROK military personnel experience a strict hierarchy, conflict between ranks, and geographical separation from, and limited communication with, families and loved ones, which can cause psychological tension, anxiety and depression. ${ }^{78}$ Maladaptive psychological conditions, such as depression, can have a negative effect on job satisfaction and organisational commitment. ${ }^{9}$ In addition, depression in military leaders can negatively affect the soldiers that they manage, representing a significant threat to the ability of fighting forces.

According to the Ministry of National Defense's Depressive Index survey, the prevalence of depression was $5.0 \%$ in $2016 .{ }^{10}$ In addition, from 2009 to 2018, suicide-related deaths accounted for the largest proportion of all military deaths. ${ }^{11}$ In particular, the number of military officers who committed suicide has increased, ${ }^{11}$ indicating that there is an urgent need to deal with depression and establish a mental health policy for these officers.

Social support can improve one's mental health and act as a protective factor against depression. ${ }^{12}$ A study conducted in the United States reported that military social support acted as a buffer against post-traumatic stress symptoms, and it became more important at higher levels of stress. ${ }^{13}$ Social support has been defined as a factor that allows individuals to overcome a situation with the use of positive resources and can be classified into four categories. ${ }^{14}{ }^{15}$ Emotional support is the provision of respect, trust, love, care and concern for another. Instrumental support is the provision of material assistance, such as goods, money, labour or one's time. Informational support is the provision of advice, suggestions, information and directives, which can be used to help solve a person's problem. Appraisal support is the provision of specific information about the individual's role, performance and behaviour, to enable self-assessment. It includes feedback and social comparison. One's superior plays an important role in the workplace and is often in the position of providing emotional, instrumental, informational and appraisal support to the supervisee. Several studies have found that different types of social support may have unique influences on depression. ${ }^{16}{ }^{17}$ In particular, research has shown that emotional support is a more important protective factor than instrumental support. ${ }^{16}$ 
Most previous research into mental health in the military has focused on soldiers' stress and maladjustment, but few studies have examined depression in military officers. As military officers have responsibility for leading and guiding soldiers, it is crucial to understand what characteristics are associated with depression and how perceived social support from one's superior is a protective factor. Given that support from one's superior may play an important role in depression in military officers, this study aimed to investigate the positive effects of the four types of social support on their depression.

\section{METHODS}

Participants

This study used raw data from the Military Health Survey (MHS) conducted in 2015. The data were obtained with the dean's approval from the medical school that conducted the survey. The institutional review board of the ROK Armed Forces Medical Command(AFMC) provided formal ethics approval for use of the MHS dataset (institutional review board approval number AFMC-15060-IRB-15-049). The objective of the MHS is to identify health-related lifestyles, levels of mental and psychological health, and satisfaction with military medical institutions, of military service personnel in order to establish military health policies. Of all the participants in the 2015 MHS, only commissioned, non-commissioned, and warrant officers were selected for inclusion in this study. The final sample consisted of 2047 officers. The characteristics of the participants are presented in Table 1.

\section{Measures}

The Korean version of the Beck Depression Inventory (K-BDI) was used to measure depression. The BDI is a 21-item self-report scale designed to assess the presence of depression and the severity of depressive symptoms, including cognitive, emotional, motivational and physical symptoms. Items are rated on a fourpoint Likert scale ranging from 0 to 3 and are summed to create a total depression score. Scores can range from 0 to 63 . The K-BDI provides the following cut-off points: 0-9 (no depression), 10-15 (mild depression), 16-23 (moderate depression) and 24-63 (severe depression). In this study, participants who received a score of 10 or higher were classified as the depressed group.

To assess support from one's superior, we used a questionnaire that was constructed for use with the Korean military, ${ }^{18}$ which included the following items: "Superior gives advice to help me do well in military life," "Superior makes me feel emotionally loved," "Superior helps me materially (food, money, etc) when I need it" and "Superior values and respects my abilities and qualities." Possible responses included "not at all," "no," "usually," "yes" and "very much." In this study, those who responded "not at all" or "no" were classified as the non-supported group, and those who responded with "usually," "yes" or "very much" were classified as the supported group.

Participants were asked questions relating to sociodemographic, military-related and health-related factors. Sociodemographic factors included gender, marital status and level of education. Military-related factors included military type, branch, rank, working area, service classification and working hours per week. Health-related factors included questions on smoking, subjective health status, having an accident during military service, suicidal ideation and experiencing stress.

\section{Statistical analyses}

A chi-square test was conducted to evaluate the association between participants' characteristics and depression. Logistic regression analysis was performed to determine the effect of each variable on depression using odds ratios (ORs) and 95\% confidence intervals (CIs). Additionally, a subgroup analysis was performed according to the four types of support. All analyses were performed using the SAS programme (9.4 version, SAS Institute, Cary, North Carolina, USA), and the significance level was set at $\mathrm{p}<0.05$.

\section{RESULTS}

Table 1 shows the results on the relations between the participants' characteristics and depression. We found that 177 (8.6\%) of the 2047 military officers were experiencing depression, and depression had a statistically significant relationship with support from one's superior, gender, marital status, working time, subjective health status, suicidal ideation, and stress $(\mathrm{p}<0.05)$. The prevalence of depression was higher in women $(12.8 \%)$, those who were unmarried $(9.8 \%)$ and military personnel who worked 49 or more hours per week (9.7\%). Additionally, depression was more common in military personnel who reported poor health $(35.8 \%)$, suicidal ideation (61.9\%) and experiencing stress (19.2\%).

Table 2 shows the results of a logistic regression analysis on the effects of participants' characteristics on depression in military personnel. Military officers who felt unsupported by their superiors were more likely to experience depression $(\mathrm{OR}=2.09$, 95\% CI 1.30 to 3.36). Perceiving one's health status as less than good increased the probability of experiencing depression (good: reference; normal: $\mathrm{OR}=3.38,95 \% \mathrm{CI} 2.21$ to 5.18 ; bad: $\mathrm{OR}=10.75,95 \% \mathrm{CI} 6.31$ to 18.30$)$. Additionally, having suicidal ideation $(\mathrm{OR}=14.05,95 \% \mathrm{CI} 5.17$ to 38.20$)$ or experiencing stress $(\mathrm{OR}=3.56,95 \% \mathrm{CI} 2.45$ to 5.17$)$ increased the probability of depression. No other characteristics had a significant effect on experiencing depression.

We performed a subgroup analysis on those with depression, depending on whether or not their superiors were supported by covariates (Table 3 ). Only in the army military officers was depression more likely to occur in the group who did not get support from their superior compared with those who felt they had received support from their superior. There was no significant difference for the navy/marines and air force officers for the effect of social support. There was a higher probability of experiencing depression in the combat group $(\mathrm{OR}=2.51,95 \% \mathrm{CI}$ 1.33 to 4.76$)$ and long-term military service group $(\mathrm{OR}=2.50$, $95 \%$ CI 1.25 to 5.00 ) when military officers felt that they did not receive support from their superior. Those officers who felt healthy $(\mathrm{OR}=3.36,95 \% \mathrm{CI} 1.13$ to 9.97$)$ or were experiencing stress $(\mathrm{OR}=2.22,95 \% \mathrm{CI} 1.19$ to 4.15$)$ were more likely to experience depression if not feeling supported. For education level, working time, and suicidal ideation, the ORs of experiencing depression were higher when the military officers felt they were not receiving support (educational levels (high school or less: $\mathrm{OR}=4.11,95 \% \mathrm{CI} 1.10$ to 15.37 ; college or more: $\mathrm{OR}=1.90$, 95\% CI 1.14 to 3.17 ), working time ( $\leq 48$ hours: $\mathrm{OR}=2.98$, $95 \% \mathrm{CI} 1.09$ to $8.14, \geq 49$ hours: $\mathrm{OR}=1.80,95 \% \mathrm{CI} 1.04$ to 3.11 ), suicidal ideation (yes: $\mathrm{OR}=3.32,95 \% \mathrm{CI} 1.32$ to 3.52 ; no: $\mathrm{OR}=1.85,95 \% \mathrm{CI} 1.15$ to 2.97$)]$.

We conducted a logistic regression analysis to investigate the effect of the type of support from one's superior (emotional, instrumental, informational and appraisal support). The results are provided in Figure 1. Military officers who felt that they were not receiving emotional support $(\mathrm{OR}=2.37,95 \% \mathrm{CI} 1.31$ to 4.29$)$ or appraisal support $(\mathrm{OR}=1.56,95 \% \mathrm{CI} 1.48$ to 2.75$)$ from their superiors had a higher probability of experiencing depression. Instrumental and informational support were not statistically significant. 
Table 1 Characteristics of participants in relation to depression

\begin{tabular}{|c|c|c|c|c|c|c|c|}
\hline \multirow[b]{3}{*}{ Variable } & \multicolumn{7}{|c|}{ Depression } \\
\hline & \multicolumn{2}{|l|}{ Total } & \multicolumn{2}{|l|}{ No } & \multicolumn{2}{|l|}{ Yes } & \multirow[b]{2}{*}{$P$ value } \\
\hline & $\mathrm{n}$ & $\%$ & $n$ & $\% *$ & $n$ & $\% *$ & \\
\hline Yes & 625 & 30.5 & 601 & 96.2 & 24 & 3.8 & \\
\hline No & 1422 & 69.5 & 1269 & 89.2 & 153 & 10.8 & \\
\hline Gender & & & & & & & 0.0433 \\
\hline Marital status & & & & & & & 0.0231 \\
\hline Married & 787 & 38.4 & 733 & 93.1 & 54 & 6.9 & \\
\hline Unmarried & 1260 & 61.6 & 1137 & 90.2 & 123 & 9.8 & \\
\hline Education level & & & & & & & 0.623 \\
\hline High school or less & 388 & 19.0 & 352 & 90.7 & 36 & 9.3 & \\
\hline Air force & 637 & 31.1 & 584 & 91.7 & 53 & 8.3 & \\
\hline Branch & & & & & & & 0.6617 \\
\hline Combat & 1264 & 61.7 & 1152 & 91.1 & 112 & 8.9 & \\
\hline Non-combat & 783 & 38.3 & 718 & 91.7 & 65 & 8.3 & \\
\hline Rank & & & & & & & 0.5590 \\
\hline Commissioned officer (04-06) & 166 & 8.1 & 156 & 94.0 & 10 & 6.0 & \\
\hline Warrant and commissioned officer (W1-03) & 576 & 28.1 & 523 & 90.8 & 53 & 9.2 & \\
\hline Non-commissioned officer (E7-E9) & 317 & 15.5 & 292 & 92.1 & 25 & 7.9 & \\
\hline Non-commissioned officer (E5-E6) & 988 & 48.3 & 899 & 91.0 & 89 & 9.0 & \\
\hline Working area & & & & & & & 0.5019 \\
\hline Ground operations command & 1187 & 58.0 & 1077 & 90.7 & 110 & 9.3 & \\
\hline$\geq 49$ & 1319 & 64.4 & 1191 & 90.3 & 128 & 9.7 & \\
\hline Smoking & & & & & & & 0.3920 \\
\hline Current smoker & 1050 & 51.3 & 959 & 91.3 & 91 & 8.7 & \\
\hline Former smoker & 117 & 5.7 & 103 & 88.0 & 14 & 12.0 & \\
\hline Non-smoker & 880 & 43.0 & 808 & 91.8 & 72 & 8.2 & \\
\hline Subjective health status & & & & & & & $<0.0001$ \\
\hline Good & 1132 & 55.3 & 1096 & 96.8 & 36 & 3.2 & \\
\hline Normal & 781 & 38.2 & 688 & 88.1 & 93 & 11.9 & \\
\hline Bad & 134 & 6.5 & 86 & 64.2 & 48 & 35.8 & \\
\hline Accident during military service & & & & & & & 0.0718 \\
\hline Yes & 113 & 5.5 & 98 & 86.7 & 15 & 13.3 & \\
\hline No & 1934 & 94.5 & 1772 & 91.6 & 162 & 8.4 & \\
\hline Suicidal ideation & & & & & & & $<0.0001$ \\
\hline Yes & 21 & 1.0 & 8 & 38.1 & 13 & 61.9 & \\
\hline No & 2026 & 99.0 & 1862 & 91.9 & 164 & 8.1 & \\
\hline Stress & & & & & & & $<0.0001$ \\
\hline Yes & 647 & 31.6 & 523 & 80.8 & 124 & 19.2 & \\
\hline No & 1400 & 68.4 & 1347 & 96.2 & 53 & 3.8 & \\
\hline Total & 2047 & 100 & 1870 & 91.4 & 177 & 8.7 & \\
\hline
\end{tabular}

*Percentage of total in the same category.

\section{DISCUSSION}

This study investigated the effect of support from one's superior on depression among ROK military officers. Because military personnel are exposed to significant stressors that can lead to mental disorders, it is important to understand how social support from one's superior might serve as a protective 


\section{Original research}

\begin{tabular}{|c|c|}
\hline & Depression \\
\hline Variable & OR $(95 \% \mathrm{Cl})$ \\
\hline \multicolumn{2}{|l|}{ Support from superior } \\
\hline Yes & 1.00 \\
\hline No & 2.09 (1.30 to 3.36$)$ \\
\hline \multicolumn{2}{|l|}{ Gender } \\
\hline Male & $0.64(0.35$ to 1.18$)$ \\
\hline Female & 1.00 \\
\hline \multicolumn{2}{|l|}{ Marital status } \\
\hline Married & 0.85 (0.51 to 1.42$)$ \\
\hline Unmarried & 1.00 \\
\hline \multicolumn{2}{|l|}{ Education level } \\
\hline High school or less & $1.43(0.90$ to 2.27$)$ \\
\hline College or more & 1.00 \\
\hline \multicolumn{2}{|l|}{ Military type } \\
\hline Army & 1.00 \\
\hline Navy, marine & 0.97 (0.56 to 1.69$)$ \\
\hline Air force & $1.12(0.63$ to 2.00$)$ \\
\hline \multicolumn{2}{|l|}{ Branch } \\
\hline Combat & 1.00 \\
\hline Non-combat & 0.94 (0.60 to 1.47$)$ \\
\hline \multicolumn{2}{|l|}{ Rank } \\
\hline Commissioned officer (04-06) & 1.11 (0.46 to 2.66$)$ \\
\hline Warrant officer and commissioned officer (W1-03) & $1.19(0.76$ to 1.87$)$ \\
\hline Non-commissioned officer (E7-E9) & 1.16 (0.63 to 2.16$)$ \\
\hline Non-commissioned officer (E5-E6) & 1.00 \\
\hline \multicolumn{2}{|l|}{ Working area } \\
\hline Ground operations command & $1.07(0.67$ to 1.71$)$ \\
\hline Capital area and all military headquarters & $1.58(0.60$ to 4.18$)$ \\
\hline Second operation command & 1.00 \\
\hline \multicolumn{2}{|l|}{ Service classification } \\
\hline Long-term military service & $0.90(0.58$ to 1.39$)$ \\
\hline Short-term military service & 1.00 \\
\hline \multicolumn{2}{|l|}{ Working time (hours per week) } \\
\hline$\leq 48$ & 1.00 \\
\hline$\geq 49$ & $1.22(0.81$ to 1.85$)$ \\
\hline \multicolumn{2}{|l|}{ Smoking } \\
\hline Current smoker & 1.01 (0.66 to 1.55$)$ \\
\hline Former smoker & 1.39 (0.69 to 2.81$)$ \\
\hline Non-smoker & 1.00 \\
\hline \multicolumn{2}{|l|}{ Subjective health status } \\
\hline Good & 1.00 \\
\hline Normal & $3.38(2.21$ to 5.18$)$ \\
\hline Bad & 10.75 (6.31 to 18.30 \\
\hline \multicolumn{2}{|l|}{ Accident during military service } \\
\hline Yes & 1.37 (0.73 to 2.58$)$ \\
\hline No & 1.00 \\
\hline \multicolumn{2}{|l|}{ Suicidal ideation } \\
\hline Yes & 14.05 (5.17 to 38.20 \\
\hline No & 1.00 \\
\hline \multicolumn{2}{|l|}{ Stress } \\
\hline Yes & $3.56(2.45$ to 5.17$)$ \\
\hline No & 1.00 \\
\hline
\end{tabular}

factor. A survey of 2047 military officers showed that 177 $(8.6 \%)$ respondents could be classified as experiencing depression, which is higher than the prevalence of a major depressive disorder in adult men in Korea. Given the relatively higher rate of depression, increased awareness of depression in military leaders and prevention and intervention strategies are needed.
Table 3 Subgroup analysis of depression and support from one's superior by covariates

\begin{tabular}{|c|c|c|}
\hline \multirow[b]{3}{*}{ Variable } & \multicolumn{2}{|l|}{ Depression } \\
\hline & $\begin{array}{l}\text { Support from a } \\
\text { superior }\end{array}$ & $\begin{array}{l}\text { No support from a } \\
\text { superior }\end{array}$ \\
\hline & OR & OR $(95 \% \mathrm{Cl})$ \\
\hline \multicolumn{3}{|l|}{ Education level } \\
\hline High school or less & 1.00 & 4.11 (1.10 to 15.37$)$ \\
\hline College or more & 1.00 & 1.90 (1.14 to 3.17$)$ \\
\hline \multicolumn{3}{|l|}{ Military type } \\
\hline Army & 1.00 & 2.45 (1.26 to 4.78$)$ \\
\hline Navy, marine & 1.00 & 4.72 (0.88 to 25.44$)$ \\
\hline Air force & 1.00 & 1.26 (0.57 to 2.78$)$ \\
\hline \multicolumn{3}{|l|}{ Branch } \\
\hline Combat & 1.00 & 2.51 (1.33 to 4.76$)$ \\
\hline Non-combat & 1.00 & 1.54 (0.73 to 3.26$)$ \\
\hline \multicolumn{3}{|l|}{ Service classification } \\
\hline Long-term military service & 1.00 & $2.50(1.25$ to 5.00$)$ \\
\hline Short-term military service & 1.00 & 1.64 (0.85 to 3.17 ) \\
\hline \multicolumn{3}{|l|}{$\begin{array}{l}\text { Working time (hours per } \\
\text { week) }\end{array}$} \\
\hline$\leq 48$ & 1.00 & 2.98 (1.09 to 8.14$)$ \\
\hline$\geq 49$ & 1.00 & $1.80(1.04$ to 3.11$)$ \\
\hline \multicolumn{3}{|l|}{ Subjective health status } \\
\hline Good & 1.00 & 3.36 (1.13 to 9.97$)$ \\
\hline Normal & 1.00 & $1.58(0.86$ to 2.90$)$ \\
\hline Bad & 1.00 & 3.16 (0.87 to 11.53$)$ \\
\hline \multicolumn{3}{|l|}{ Suicidal ideation } \\
\hline Yes & 1.00 & 3.32 (1.32 to 3.52$)$ \\
\hline No & 1.00 & 1.85 (1.15 to 2.97$)$ \\
\hline \multicolumn{3}{|l|}{ Stress } \\
\hline Yes & 1.00 & 2.22 (1.19 to 4.15$)$ \\
\hline No & 1.00 & 1.85 (0.87 to 3.93 ) \\
\hline
\end{tabular}

Those officers who felt they did not receive support from their superior were more likely to be depressed, supporting the results of previous studies. In addition, the prevalence of depression was higher in women, and in those who were not married, worked longer hours per week, had poorer subjective health, reported having suicidal ideation and were experiencing stress. These results are partially consistent with previous studies. ROK armed forces needs to consider military personnel who have any of these characteristics as vulnerable

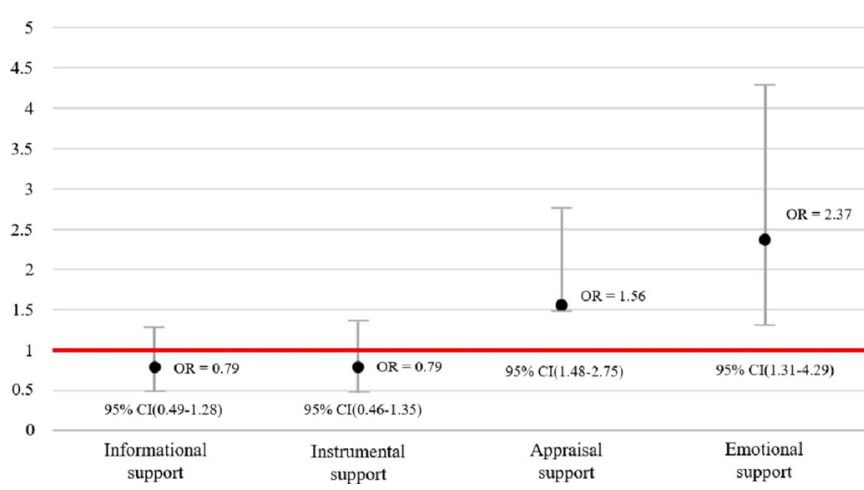

Figure 1 Analysis of types of support from one's superior. Participants who felt they were getting support from their superior were the reference group. 
to, or at-risk of having, depression, and identify and systematically manage depression where indicated.

Social bonds and social support of military peers can have positive effects on the mental health of soldiers. ${ }^{19}$ Additionally, a previous study highlighted the importance of support from one's superior, showing that a commander's leadership or attention to maladjustment in soldiers has a positive effect on the mental health of military service personnel. ${ }^{20}$ In the controlled, hierarchical environment of the military, a superior's support is a protective factor for depression that can be easily implemented. Lastly, we confirmed that those officers who felt that they did not receive emotional or appraisal support from their superiors were more likely to experience depression. Instrumental and informational support had no effect on depression. Thus, it is especially important for superior military personnel to learn about, and know how to provide, emotional and appraisal support to their subordinates. By paying attention to the needs of subordinates and providing support, superiors' can effectively prevent and mitigate depression in military officers.

Our research had several limitations. First, it is difficult to determine causality because this study is based on cross-sectional data. Additionally, common method bias can occur because all variables were measured by self-report questionnaires in the same respondents. Second, we used the BDI to measure depression. However, in some studies, a high BDI score was obtained even when no psychiatric disorder was present or no depression was diagnosed. Therefore, higher BDI scores do not necessarily mean that a person is clinically depressed. ${ }^{21}$ In order to diagnose a person as having a mood disorder, it would be necessary to gather information through a clinical interview and possibly, other questionnaires or psychological tests. Additionally, although the original BDI cut-off score is 16 points ${ }^{22}$ we used 10 points because few military officers had scores indicating that they were experiencing a severe level of depression. We also considered that officers and non-commissioned officers have a tendency to hide their depression owing to the military atmosphere, which meant that there is no differentiation between those who were experiencing a mild versus moderate versus severe level of depression in our study. Lastly, we did not have more recent data because the MHS has not been conducted again since 2015. Thus, we do not know if the findings are currently generalisable to officers in the ROK armed forces.

Despite these limitations, this study has the following strengths. First, the MHS consists of a representative sample by considering the rank, branch, and regional distribution of military personnel in investigating the health behaviour and medical care of soldiers. Second, in contrast to previous studies conducted mainly on soldiers, this study assessed the prevalence of depression of military officers and highlighted the importance of managing it. Third, we identified factors that can have a negative effect on the mood of military officers and confirmed the positive effects of social support from superiors. Our findings are consistent with the results of previous studies examining support from superiors and may be a theoretical basis for preparing and establishing an educational programme for social support in the ROK armed forces. Fourth, by classifying the superiors' support by type, the effect of support was presented in more detail and allowed us to determine the type of support that is most helpful in preventing and alleviating depression.

\section{CONCLUSION}

Many studies have shown that social support has a protective effect on depression. Depression in military officers was associated with the extent to which they felt they received support from superiors. In particular, emotional and appraisal support showed a significant association with improving depression.

Based on the findings, we suggest that the ROK armed forces should consider the identified risk factors for depression and provide early intervention and management for high-risk groups. Programmes are needed to develop and improve superiors' ability to provide social support. Counselling skills should be developed for each type of support, and an organisational atmosphere within the military would need to be created to promote such a training programme. Finally, a continuous mental health survey is needed.

Contributors SYW, HJK and E-CP planned the study. HJK analysed the secondary data. HCA, BRK and BNJ collected material for the study. SYW wrote the paper and submitted the study.

Funding The authors have not declared a specific grant for this research from any funding agency in the public, commercial or not-for-profit sectors.

Competing interests None declared.

Patient consent for publication Not required.

Provenance and peer review Not commissioned; internally peer reviewed.

Data availability statement Data are available upon reasonable request.

Open access This is an open access article distributed in accordance with the Creative Commons Attribution Non Commercial (CC BY-NC 4.0) license, which permits others to distribute, remix, adapt, build upon this work non-commercially, and license their derivative works on different terms, provided the original work is properly cited, appropriate credit is given, any changes made indicated, and the use is non-commercial. See: http://creativecommons.org/licenses/by-nc/4.0/.

\section{ORCID iD}

H J Kim http://orcid.org/0000-0001-7007-8442

\section{REFERENCES}

1 World Health Organization. Depression and other common mental disorders: global health estimates. World Health Organization, 2017.

2 Mathers CD, Loncar D. Projections of global mortality and burden of disease from 2002 to 2030. PLoS Med 2006;3:e442.

3 Pyo HJ, Woo LD, Hahm BJ, et al. The survey of mental disorders in Korea. Sejong, Republic of Korea: Samsung Hospital, 2016.

4 Organization for Economic Cooperation and Development. Health at a glance 2017: OECD indicators. Paris: Organization for Economic Cooperation and Development, 2017.

5 Greden JF. Workplace mental health programmes: the role of managers. Lancet Psychiatry 2017:4:821-3.

6 Park K-0, Wilson MG, Lee MS. Effects of social support at work on depression and organizational productivity. Am J Health Behav 2004;28:444-55.

7 Park HC. A study on the quality of life improvement of soldier: focusing on the stressor social support. University of Yonsei, 2001.

8 Warner $\mathrm{CM}$, Warner $\mathrm{CH}$, Breitbach J, et al. Depression in entry-level military personnel. Mil Med 2007;172:795-9.

9 CS Y, Park IJ, Sohn YW. The relationships of learned helplessness, depression, organizational commitment and job engagement: focusing on depression as a mediator and calling as a Moderator. Korean Journal of Culture and Social Issues 2016;22:431-53

10 Republic of Korea Ministry of National Defense. Depression index survey. Seoul, Republic of Korea: Republic of Korea Ministry of National Defense, 2016.

11 Republic of Korea Ministry of National Defense. Defense statistics annual report. Seoul, Repulic of Korea: Republic of Korea Ministry of National Defense, 2018.

12 Marroquín B. Interpersonal emotion regulation as a mechanism of social support in depression. Clin Psychol Rev 2011;31:1276-90.

13 Smith BN, Vaughn RA, Vogt D, et al. Main and interactive effects of social support in predicting mental health symptoms in men and women following military stressor exposure. Anxiety Stress Coping 2013;26:52-69.

14 Caplan G. Support systems and community mental health: lectures on concept development. Behavioral Publications, 1974.

15 House JS, Kahn R. Measures and concepts of social support. In: Cohen S, Syme SL eds. Social support and health. New York: Academic Press. Inc, 1981: 83-108.

16 Gariépy G, Honkaniemi H, Quesnel-Vallée A. Social support and protection from depression: systematic review of current findings in Western countries. Br J Psychiatry 2016;209:284-93. 


\section{Original research}

17 Mathieu M, Eschleman KJ, Cheng D. Meta-analytic and multiwave comparison of emotional support and instrumental support in the workplace. J Occup Health Psychol 2019;24:387-409.

18 Hyun HS, Lee IS. A study on stress and symptoms of stress in soldiers in the army. $J$ Korean Acad Nurs 2008;38:238-47.

19 Kim JY, Seo JY, Jang DY. The effect of job insecurity on depression of junior NCOs in the Republic of Korea military: focused on social connectedness as moderator. Korean Academy of Military Social Welfare 2018;11:61-84.
20 Kim S, Kim HL, Woo C, et al. Communication abilities, interpersonal relationship, anxiety, and depression in Korean soldiers. Journal of Korean Academy of Psychiatric and Mental Health Nursing 2011;20:81-90.

21 Kendall PC, Hollon SD, Beck AT, et al. Issues and recommendations regarding use of the Beck depression inventory. Cognit Ther Res 1987:11:289-99.

22 Lee YH, Song JY. A study of the reliability and the validity of the BDI, SDS, and MMPI-D scales. Korean Journal of Clinical Psychology 1991;10:98-113. 